\title{
Corruption and the soundness of banking systems in middle-income countries
}

\author{
Tran Hung Son, Nguyen Quynh Cac Mai, Nguyen Thanh Liem
}

\begin{abstract}
The paper examines the impact of corruption on the soundness of banking systems in middle-income countries. The findings show that corruption exacerbates the soundness of banking systems in those countries. This implies that increased corruption leads to banks more prone to taking risks and a rise in non-performing loans, rendering higher probability of crises. The results from robustness test yields consistent results. In addition, the results of the study show that the bankspecific variables as well as those related to regulations and institutional quality can also affect the health of banking systems in middle-income countries.
\end{abstract}

Index Terms-Corruption, banking systems, soundness, middle-income countries...

\section{INTRODUCTION}

$\mathrm{M}$ any studies have analyzed the corruption effects on the economy in general, but there is limited research of its impacts on financial intermediaries and banks. Meanwhile, banks act as the lifeblood of an economy, providing the majority of financial resources for the economy, especially in middle-income countries.

Studies have shown two possible financial effects of corruption: positive and negative. Mauro (1995) shows that effectiveness of projects will faciliate further by bribing politicians and banks to get credit approvals [1]. However, Khwaja and Mian (2005) argue that companies that are in contact with politicians can get bank loans soon but have a higher default rate; or Charumilind et al. (2006) show that firms with close connection

Received June, 16 $6^{\text {th }}, 2017$; Accepted Dec, $8^{\text {th }} 2017$.

Tran Hung Son, University of Economics and Law, VNUHCM (e-mail: sonth@uel.edu.vn);

Nguyen Quynh Cac Mai, University of Economics and Law, VNU-HCM;

Nguyen Thanh Liem,University of Economics and Law, VNU-HCM (e-mail: liemnt@uel.edu.vn). with politicians can access long-term bank credit with less collateral requirement, leaving too much risk for banks $[2,3]$. Corruption in lending is one of the major causes of problematic loans in many countries.

On the other hand, corruption may cause misallocation of loans, raising firms' default probabilities by increasing cost of capital and reducing the effectiveness of the company's use of loans. Banks with low asset quality will operate poorly and are prone to crisis, as stated by Park (2012) corruption is one contributing factor to the financial crisis through its adverse impact on banks' assets [4].

Our topic of interest is the relationship between corruption and the soundness of banking systems in middle-income countries. We select those countries as there are limited studies on the financial outcome of corruption here. Moreover, this is a group of countries with high levels of corruption (Transparency International, 2016), so those nations are more likely to suffer from the destructive effect of corruption [5]. Besides, as stated in Laeven and Valencia (2012), middleincome economies are countries with high incidence of banking crises and financial crises in the world [6].

Although it is highly likely that a country with highly corrupt like usually has a highly corrupt banking sector, corruption does not necessarily lead to bad loans in the banking sector. A highly corrupt country does not necessarily have a greater number of bad loans than a country with lower corruption. Accordingly, the relationship between corruption and bad loans needs to be verified empirically. This study focuses mainly on the financial impact of corruption on the soundness of banking operations, particularly through its impact on credit quality of loans. Corruption may cause banks to be exposed to excessive risk, more willing to shoulder non-performing loans, thus 
forcing the whole system to crisis more easily. If our arguments are supported by empirical results, this paper may contribute to existing literature in two important ways. First, in terms of scientific and practical values, our paper contributes to the growing empirical studies for corruption-finance literature. We offer a possible explanation of why crises have taken more often in countries with more serious levels of corruption like middleincome countries. Second, we provide evidence on the impact of corruption using a sample of 102 middle-income countries from 2003-2013, and this helps extend Park (2012) in that the latter study only examines a sample of 70 economies in a short window (2002-2004) [4]. The extension of the time window and the use of panel regression method as in our paper not only aid in the findings regarding long-term impact of the regressors, but also provide more robust results in comparison with Park (2012) which only employs pooled OLS [4]. Our paper also expands the scope of Bougatef (2015), for this paper only specializes in Islamic banks while credit risk preferences and tolerance may differ significantly between Islamic banks and conventional banks [7]. Finally, several implications for policymakers in middle-income countries are suggested to harness the likely effects of corruption on the soundness of banking systems.

\section{THEORETICAL BACKGROUND ON THE FINANCIAL IMPACT OF CORRUPTION ON THE SOUNDNESS OF BANKING SYSTEM}

According to corruption-finance literature, corruption may affect the soundess of a bank in three aspects. Firstly, corruption causes banks to accept risks more willingly. Corruption is usually accompanied by the tacit government support in order for firms to access the bank's capital more easily, risking increased probability of non performing loans and lack of transparency as well as stability of the banks' operations. Khwaja and Mian (2005) and Charumilind et al. (2006) show that firms that own links to officials/politicians will be able to attain bank loans but finally result in higher default rate and high risks for the banks, triggering financial crises $[2,3]$.

In addition, the more corrupt a country is, the more risk a banking system is prone to. An example is when a country adopts broadened monetary policy, interest rates fall, asset values increase and banks tend to make comprise with more risk to assure its profit margins. In such circumstance, the existence of corruption will further accelerate the risk tolerence of banks (Chen et al., 2015) [8]. Thus, corruption has undermined the integrity of banks as well as the whole banking system, rendering a country vulnerable to a financial crisis. However, under certain circumstances, corruption has a positive effect: for truly effective projects, bribing officials and banks can speed up the time needed for credit assessment, boosting the probability of success.

Secondly, corruption is also a cause for the rise in capital costs. In countries with high corruption levels, companies have to go through "doors" to access capital quickly, when the cost of capital of these firms increase highly. On the other hand, for high-risk loan projects, banks are forced to raise lending rates to offset risks, which is termed "corruption premium" by Munshi (1999) [9]. Akins et al. 2015 show that banking systems can identify the risk of capital loss but still cannot reduce the adverse impact of corruption in lending activities if the government holds high ownership ratios or deposit insurance agencies [10].

Thirdly, the soundness of banking system will be affected by the inefficient allocation of bank capital. Corruption causes projects to need more capital than other projects, leading to a decline in the quality of private investments and lowering the ability to make payment of loans. Bougatef (2015) provide evidence that the corruption level aggravates the problem of impaired financing. This in general affects the soundness of banking activities and economic growth. In other words, banks are a channel that transfer the impact of corruption on economic growth (Park, 2012) [4, 7].

\section{RESEARCH METHODOLOGY}

\section{Data}

We collect research data comprising 102 middle-income countries in 6 regions, among which 52 are low middle-come countries and 50 high middle-income. The data are derived from World Bank, IMF, World Economic Forum. The Corruption Perceptions Index (CPI) is collected from the Transparency International (TI) website. For a number a reasons, some countries do not have full data, resulting in an unbalanced panel data from 2003-2013.

\section{Research models}

Based on the presented theoretical background, the research model is as follows:

$$
\begin{gathered}
Y_{i, t}=c+\beta_{1} \cdot \operatorname{LnCI}_{i, t}+\beta_{2} \cdot \text { RGDP }_{i, t}+\beta_{3 . I N F_{i, t}+}+ \\
\beta_{4 . H H C G D P_{i, t}+\beta_{5} \cdot \text { LIQ }_{i, t}+\beta_{6} \cdot \text { Efficiency }_{i, t}+}
\end{gathered}
$$


$\beta_{7}$ LnCAP $_{i, t}+\beta_{8 .}$ IRS $_{i, t}+\beta_{9 . \text { Voac }_{i, t}+\beta_{10} . \text { Psnov }_{i, t}+}+$ $\beta_{11}$ Gove $_{i, t}+\beta_{12} \cdot$ Req $_{i, t}+\beta_{13} \cdot$ Rol $_{i, t}+\beta_{14} \cdot D I_{i, t}+\varepsilon_{i, t}$

Where $Y_{i}$ is the dependent variable that measures the soundness levels of banks. We use the ratio of overdue debt/total outstanding loans (Park, 2012, Bougatef, 2015) or non-performing loan ratio (NPL) $[4,7]$. The loan quality (asset quality of banks) plays an important role in assessing a bank's financial health as lending activity is considered its core activity (Park, 2012) [4]. In addition, NPL is among the indicators that gauge the soundness of banking operations (IMF, 2006) [11]. The higher the ratio, the lower the soundness level of banks and vice versa.

\section{Independent variables}

CI (corruption index): calculated from the CPI (Corruption Perceptions Index). CPI is the measure of the corruption perception at the national level. The lower the CPI, the lower the corruption of a country. The CPI has a scale from 0 to 10 . The CI corruption index is calculated as: $\mathrm{CI}=10-\mathrm{CPI}$.

$\mathrm{CI}$ is used to measure the overall level of corruption for a country. The higher the CI, the higher the degree of corruption and increase the likelihood of a bank accepting risks. The above analysis shows that the corruption index and NPL is positively correlated. Because CI has a high standard deviation, so in the model uses the natural logarithm of CI to represent the corruption variable, denoted as LnCI.

Group variables related to bank characteristics

IRS - interest rate spread (lending interest rate deposit rate). This indicator represents the bank's profitability but does not take into account other costs other than interest rates. Higher IRSs imply that banks may be involved in very risky lending activities. IRS has positive correlation with nonperforming loan ratio.

Efficiency - Bank overhead costs to total assets. The higher the ratio, the less effective the bank is, reducing the bank's stability. It is expected that there is a positive link between efficiency and nonperforming loan ratio.

LIQ - liquid assets/(short term loans + total deposits): this indicator shows the ability to ensure the bank liquidity. The higher the ratio, the higher level of bank soundness (Chen et al., 2015). LIQ is inversely related to the non-performing loan ratio.

LnCAP - the logarithm of CAP (CAP = equity/total assets ratio): this represents capital adequacy. We use CAP instead of CAR (promulgated by Basel Committee) to mitigate the problem of endogeneity connected with the latter (Park, 2012). The higher the ratio, the less banks are involved in risky operations so LnCAP is inversely related to non-performing loan ratio.

Group of variables on regulation and institutional quality

WGI - World Governance Indicators. These indicators are collected from World Bank's database, consisting of 6 indicators that measure the institutional quality of country encompassing legal system, economic freedom, political stability, freedom of speech... These indicators directly/indirectly affect the banking operations. Among these indicators we do not utilize Control of Corruption indicator since this is similar to CPI, the remaining 5 are as follows:

Voac - Voice and Accountability: measure freedom of speech, press freedom with a rating of 2.5 to 2.5 .

Psnov - Political stability no violence: measure the political stability (in terms of terrorism, riots and coups)

Gove - Government Effectiveness: measure the quality of public services, with rating from -2.5 to 2.5

Req - Regulatory quality: measure the awareness of government in making and executing the policies that allows and facilitates the development of private sector.

Rol - Rule of Law: measure the rigidity of the law (contract enforcement, property rights, court action, criminal capacity and violence), with a rating of -2.5 to 2.5 .

DI - Deposit Insurance: dummy variable which equals 1 for countries where there are compulsory deposit insurance agencies in place. Those agencies protect depositors and assist banks in paying depositors when there is unfavorable information. However if the deposit insurance agency has enough power and tools to perform its function, its influence can overwhelm the influence of moral hazard. Hence the relationship between DI and the healthiness of a bank may be of both directions.

Group of variables on macroeconomic environment

RGDP - Real GDP growth: represent the macroeconomic environment. When the economy grows, the non-performing loan ratio will decrease as the repayment capacity of individuals and businesses increases. So, RGDP is expected to 
have a negative correlation with non-performing loan ratio.

INF - Inflation: this factor may drive up interest rates, causing the inability to repay many unsecured loans. In addition, Chen et al. (2015) show that bank risks rise in periods of high inflation, so we expect a positive relationship between inflation and non-performing loan ratio [8].

HHCGDP - Household expenditure (\% of GDP). Household spending represents personal credit and is considered one of the factors that affect non-performing loan ratio (Park, 2012) [4]. We expect a positive correlation between household expenditure and non-performing loan ratio.

\section{RESEARCH FINDINGS AND DISCUSSION}

Descriptive statistics and correlation coefficients
Table 1 briefly outlines the basic parameters of the research variables. The average corruption level (CI) is 6.637, with the lowest being 1 and highest 8.9. For the dependent variable the nonperforming loan ratio is $7.1 \%$ on average, higher than the median value of $4.4 \%$.

The results of the correlation matrix in Table 2 show that Gove variable has a high correlation with the remaining variables, especially the correlation coefficient between Gove and Rol is 0.823. To solve the multicollinearity, the estimation of efficiency we remove the Gove variable from the model (Gove is not significantly related to the dependent variable). After removing Gove, the result of VIF test passes, suggesting no multicollinearity in the model (Table 3).

TABLE 1

DESCRIPTIVE STATISTICS

\begin{tabular}{|c|c|c|c|c|c|c|c|c|}
\hline Variable & Obs & Mean & Median & Std. Dev. & Min & Max & Skewness & Kurtosis \\
\hline NPL & 724 & 0.071 & 0.044 & 0.063 & 0.000 & 0.453 & 1.552 & 5.993 \\
\hline LnCI & 983 & 1.931 & 6.900 & 0.2239 & 0.000 & 2.186 & -2.518 & 13.712 \\
\hline RGDP & 1116 & 0.049 & 0.050 & 0.060 & -0.620 & 1.040 & 3.215 & 89.681 \\
\hline INF & 1017 & 0.076 & 0.060 & 0.089 & -0.250 & 1.040 & 3.549 & 30.168 \\
\hline HHCGDP & 913 & 0.672 & 0.676 & 0.166 & 0.051 & 1.133 & -0.347 & 3.347 \\
\hline LIQ & 965 & 0.392 & 0.343 & 0.214 & 0.020 & 1.371 & 1.063 & 4.177 \\
\hline Efficiency & 951 & 0.043 & 0.038 & 0.030 & 0.001 & 0.275 & 2.643 & 16.323 \\
\hline IRS & 827 & 0.083 & 0.067 & 0.064 & 0.000 & 0.699 & 0.040 & 0.291 \\
\hline $\operatorname{lnCAP}$ & 619 & -2.285 & -2.298 & 0.347 & -4.206 & -1.330 & -0.506 & 5.543 \\
\hline Voac & 1034 & -0.331 & -0.182 & 0.789 & -2.210 & 1.246 & -0.275 & 2.237 \\
\hline Psnov & 1026 & -0.308 & -0.263 & 0.872 & -3.185 & 1.480 & -0.484 & 3.042 \\
\hline Req & 1028 & -0.367 & -0.344 & 0.624 & -2.675 & 1.165 & -0.312 & 2.764 \\
\hline Rol & 1034 & -0.434 & -0.486 & 0.586 & 1.083 & -1.924 & 0.315 & 2.666 \\
\hline DI & 1122 & 0.465 & 0.000 & 0.499 & 0.000 & 1.000 & 0.139 & 1.019 \\
\hline FIXED & 994 & 0.240 & 0.230 & 0.082 & 0.050 & 0.680 & 1.485 & 7.410 \\
\hline POPG & 1032 & 0.013 & 0.013 & 0.010 & -0.017 & 0.049 & -0.002 & 2.767 \\
\hline
\end{tabular}


SCIENCE \& TECHNOLOGY DEVELOPMENT JOURNAL:

ECONOMICS - LAW AND MANAGEMENT, Vol 1, No Q5 - 2017

TABLE 2

\begin{tabular}{|c|c|c|c|c|c|c|c|c|c|c|c|c|c|c|c|}
\hline & NPL & LnCI & RGDP & INF & " HHCGDP & "LIQ & Efficiency & IRS & LnCAP & Voac & Psnov & Req & Gove & Rol & $\overline{\mathrm{DI}}$ \\
\hline NPL & 1 & & & & & & & & & & & & & & \\
\hline LnCI & 0.165 & 1 & & & & & & & & & & & & & \\
\hline RGDP & -0.188 & 0.07 & 1 & & & & & & & & & & & & \\
\hline INF & 0.062 & 0.176 & 0.07 & 1 & & & & & & & & & & & \\
\hline HHCGDP & 0.02 & 0.109 & -0.159 & -0.039 & 1 & & & & & & & & & & \\
\hline LIQ & -0.05 & 0.037 & 0.043 & 0.008 & 0.051 & 1 & & & & & & & & & \\
\hline Efficiency & 0.061 & 0.201 & -0.027 & 0.168 & 0.151 & -0.042 & 1 & & & & & & & & \\
\hline IRS & -0.04 & 0.022 & -0.015 & 0.037 & -0.05 & 0.106 & 0.276 & 1 & & & & & & & \\
\hline LnCAP & 0.006 & 0.051 & -0.068 & -0.064 & 0.173 & 0.04 & 0.296 & 0.072 & 1 & & & & & & \\
\hline Voac & -0.212 & -0.258 & -0.142 & -0.168 & 0.178 & -0.029 & 0.021 & 0.228 & 0.028 & 1 & & & & & \\
\hline Psnov & -0.209 & -0.432 & -0.009 & -0.073 & -0.109 & 0.034 & -0.053 & 0.021 & 0.065 & 0.348 & 1 & & & & \\
\hline Req & -0.215 & -0.383 & -0.081 & -0.297 & 0.02 & -0.085 & 0.244 & -0.031 & -0.049 & 0.582 & 0.293 & 1 & & & \\
\hline Gove & -0.236 & -0.552 & 0.029 & -0.272 & -0.232 & 0.073 & -0.411 & -0.177 & -0.102 & 0.401 & 0.371 & 0.707 & 1 & & \\
\hline Rol & -0.112 & -0.633 & -0.035 & -0.197 & -0.097 & -0.004 & -0.401 & -0.16 & -0.093 & 0.422 & 0.555 & 0.671 & 0.823 & 1 & \\
\hline DI & 0.112 & 0.299 & -0.158 & 0.015 & 0.045 & 0.126 & 0.155 & 0.133 & 0.116 & -0.033 & -0.265 & -0.074 & -0.269 & -0.397 & 1 \\
\hline
\end{tabular}




\begin{tabular}{lcc}
\multicolumn{3}{c}{ TABLE 3 } \\
VIF TEST \\
\hline \hline \multicolumn{1}{c}{ Variable } & VIF & 1/VIF \\
\hline NPL & 1.52 & 0.66 \\
LnCI & 1.96 & 0.51 \\
RGDP & 1.17 & 0.85 \\
INF & 1.19 & 0.84 \\
HHCGDP & 1.39 & 0.72 \\
LIQ & 1.12 & 0.89 \\
Efficiency & 1.69 & 0.59 \\
IRS & 1.50 & 0.67 \\
LnCAP & 1.65 & 0.61 \\
Voac & 2.68 & 0.37 \\
Psnov & 3.06 & 0.33 \\
Req & 3.94 & 0.25 \\
Rol & 7.96 & 0.13 \\
DI & 2.09 & 0.48 \\
\hline \multicolumn{2}{c}{ Mean VIF } & $\mathbf{2 . 5 2}$ \\
\hline \hline
\end{tabular}

\section{Discussion of research findings}

We rely on tests to compare methods of Pooled OLS, Fixed Effects and Random Effects. F test (p_value $=0.0000)$ suggests that Fixed effects model is more suitable between Pooled OLS and Fixed effects models. The p-value of Breusch Pagan test is 0.0000 , showing that between Pooled OLS and Random effects model, the latter suits the data better. Finally, the p-value of Hausman test is 0.0000 , implying that between Fixed effects and Random effects models, the former is better. Therefore, in table 4 with the three tests indicate that for the data in question, the Fixed Effects (FEM) model is the most appropriate. FEM tends to provide robust results among the three popular regression methods for panel data, and is able to remove individual effects that are constant over time. The residuals of the model suffer heteroskedasticity and autocorrelation according to other tests. Therefore, we use the FEM estimation method with robust standard errors that can mitigate the above issues.

$$
\text { TABLE } 4
$$

TESTS TO COMPARE METHODS OF POOLED OLS, FIXED EFFECTS AND RANDOM EFFECTS

\begin{tabular}{ll}
\hline \hline Tests & \\
\hline F-test & $\mathrm{F}(46,299)=12.44$, \\
\multirow{3}{*}{ Breusch Pagan } & Prob $>\mathrm{F}=0.0000$ \\
& Chi_sq $(1)=83.02$, \\
Hausman & Prob $>$ Chi-sq $=0.0000$ \\
& Chi_sq $(13)=36.76$, \\
& Prob $>$ Chi_sq $=0.0000$ \\
\hline \hline
\end{tabular}

Look at Table 5, the coefficient of corruption index ( $\mathrm{LnCI})$ is 0.03 with significance at the $10 \%$ level, which indicates that corruption deteriorates the asset quality of the banking sector. As corruption in a country increases (equivalent to an increase in corruption in bank lending), banks' risk tolerance increases, and bank capital is allocated to bad projects, reducing the probability of repaying loans on time and resulting in an increase in non - performing loan ratio, suppressing the healthiness of the nation's banking system. In that way, the banking system becomes vulnerable, which supports the "sand in the wheel" theory. There is no evidence that corruption has benefited banks in middle-income countries. Government investment incentives and the implicit government's protection for financial institutions have contributed to Asian firms' seeking foreign loans (mostly short-term) regardless of risk (Chen, 2015). Therefore, there is reason to believe that corruption is one of the causes of the financial crisis in middle-income countries. These findings are in line with the work of Park (2012) and Bougatef (2015) whose work concluded that corruption significantly aggravates the problems with bad loans in the banking sector, implying that corruption is a global determinant of the loan quality in the banking sector [4, 7].

\section{For macroeconomic variables}

As expected, real economic growth (RGDP) has a significantly negative relationship with non performing loan ratio. When the economy of a middle-income country is rocketing, firms have better performance and income and so increase repayment capacity, leading to a banking system that is less risky and healthier. This result is consistent with Chen et al. (2015), while Park (2012) found no link between economic growth and non-performing loan ratio $[4,8]$.

In the presented models, the inflation rate is negative but insignificant relationship with nonperforming loan ratio. These findings are in line with the work of Fofack (2005) whose work concluded that the relationship between inflation rate and NPLs rate is insignificant [12]. However, these findings are in contrast with the study hypothesis that hypothesised a positive relationship between inflation rate and level of non - performing loan ratio as concluded by Chen et al. (2015) [8]. This contrast is not surprising as the relationship between inflation rate and level of non performing loan ratio is ambiguous based on literature. According to Nkusu (2011), inflation can affect the level of non performing loan ratio negatively or positively [13].

The study does not find a link between the household consumption rate on nominal GDP (HHCGDP) with non-performing loan ratio. 
Indeed, in some of these countries, countries with high corruption usually have less skilled loan officers; thus, they are likely to make more erroneous loan decisions when facing increasing demand for consumer loans (Park, 2012) [4].

For the group of variables related to intrinsic bank characteristics

IRS's coefficient is statistically significant at $10 \%$ and shows that the difference between the lending and deposit rates is positively correlated with the non-performing loan ratio. The greater the difference in interest rates, the more nonperforming loan ratio is, consistent with Park's (2012) [4].

Efficiency variable is significant at $5 \%$ and shows that when the management cost of banks in middle-income countries increases, the banks' soundness reduce. The high cost of management is a testimony to the ineffective performance of bank executives, and banks are more likely to take risks, consistent with our expectation and Chen et al. (2015) [8].

The coefficient of LIQ is significantly inversely correlated to non-performing loan ratio, consistent with Chen et al. (2015). This shows that when the level of bank liquidity is higher, the lower the nonperforming loan ratio. Improving bank liquidity is recommended by Basel Committee because a liquidity shortage could cause systemic collapse in the banking system.

LnCAP's is statistically significant at $10 \%$ and is inversely correlated with the ratio of nonperforming loans. This result is consistent with Park's (2012) study or a more recent study by Anjom and Karim (2016) [4, 14]. This may suggest when shareholders put more of their capital into banks, they will become more cautious in screening loans and vice versa.

For variable groups of regulation and institutional quality

The measurement of freedom of expression (Voac) is statistically significant at $5 \%$ and is inversely correlated with the ratio of nonperforming loans, in line with our expectation. This result is similar to Park's (2012) [4]. The more right to speak freely, the healthier the banking system is. Psnov and Req's coefficients government to develop and implement policies is not statistically significant.

Rol variable is statistically significant at $1 \%$ and is positively correlated to the dependent variable. This result is contrary to our expectation. Many middle-income countries fail to effectively liberalize the financial market, make information more transparent and the law tight enough. As a result, as the Rol index rises, loans that have been "beautified" will finally return to their nature, rendering increased non performing loans.

As for DI, the analysis results in table 5 show that the estimated coefficient between DI and nonperforming loans in middle-income countries is not statistically significant. This result is in contrast to those of Park (2012) and Chen et al. $(2015)[4,8]$.

TABLE 5

RESULTS FOR REGRESSION WITH FIXED EFFECTS AND ROBUST STANDARD ERRORS

\begin{tabular}{lrrr}
\hline \hline Coeff. & Std. Err & $\begin{array}{c}\text { Expected } \\
\text { sign }\end{array}$ \\
\hline LnCI & $0.030^{*}$ & 0.017 & + \\
RGDP & $-0.147 * *$ & 0.056 & - \\
INF & -0.055 & 0.036 & + \\
HHCGDP & 0.120 & 0.073 & + \\
LIQ & $-0.062^{*}$ & 0.034 & - \\
Efficiency & $0.269^{*} *$ & 0.129 & + \\
IRS & $0.309 *$ & 0.154 & + \\
LnCAP & $-0.037 *$ & 0.021 & - \\
Voac & $-0.099^{*} *$ & 0.039 & - \\
Psnov & -0.002 & 0.016 & - \\
Req & -0.038 & 0.023 & + \\
Rol & $0.126 * * *$ & 0.036 & + \\
DI & 0.014 & 0.022 & \\
Constant & -0.142 & 0.094 & \\
$\mathrm{R}^{2}$ & 0.25 & & \\
$\mathrm{~N}$ & 382 & & \\
\hline \hline$* * *, * * *$ significant at $10 \%, 5 \%$ and $1 \%$ respectively
\end{tabular}

\section{CHECK THE ROBUSTNESS OF THE MODEL (ROBUSTNESS CHECK)}

To test the robustness of the findings, we replace LnCI with WBCI (another measure of corruption) and substitute non-performing loan ratio with Z-Score. When examining the robustness of the results, we only examine the impact of corruption and so will ignore the other variables.

Replace corruption index with WBCI variable

This indicator in table 6 is calculated from the Control of Corruption index of the WGI indicator set. Control of Corruption (CC) is a measure of the level of awareness of public power made for individual benefits. $\mathrm{CC}$ is estimated to be in the range of -2.5 to 2.5 , with higher $\mathrm{CC}$ meaning less corruption. Therefore, the study uses WBCI $=0$ CC. The higher the WBCI, the higher the level of corruption in the country. 
TABLE 6

RESULTS FOR REGRESSION WITH WBCI

\begin{tabular}{llr}
\hline \hline & Coeff. & Std. Err. \\
\hline WBCI & $0.032^{* * *}$ & 0.012 \\
RGDP & $-0.362^{* * *}$ & 0.072 \\
LIQ & $-0.026^{*}$ & 0.014 \\
Efficiency & $0.192^{* *}$ & 0.097 \\
IRS & $0.133^{* *}$ & 0.053 \\
LnCAP & -0.003 & 0.009 \\
Voac & 0.002 & 0.007 \\
Rol & 0.006 & 0.013 \\
Constant & $-0.138^{* * *}$ & 0.050 \\
$\mathrm{R}^{2}$ & 0.31 & \\
N & 412 & \\
F value & $13.62 * * *$ & \\
\hline \hline$* * *, * * *:$ significant at $10 \%, 5 \%$ and 1\% respectively
\end{tabular}

WBCI's coefficients are significant and there is an impact of corruption on the health of the banking system. As CI has weaknesses in the process of collection and evaluation, we suspect a bias in the estimation results. However, using the alternative WBCI has once again reinforced the conclusion that there is a negative effect of corruption on the well-being of the banking system in middle-income countries.

Replace dependent variable by Z-Score

$\mathrm{Z}$-Score is a measure of the health of the banking system: the higher the Z-Score, the greater the level of financial stability (Laeven \& Levine, 2009; Demirgüc-Kunt \& Huizinga, 2010; Köhler, 2015) [15-17]. Chen et al. (2015) use ZScore to measure the risk tolerance of banks and determine the health of the bank [8]. Based on the Chen et al. (2015) study, this study uses the ZScore as a dependent variable to replace the nonperforming loan ratio to assess the bank's soundness.

Regression results in table 7 show that when replacing the non - perfroming loan ratio with ZScore, the impact of corruption on the banking system soundness remains unchanged. The LnCI variable is statistically significant and correlates negatively with Z-Score, indicating that as corruption increases, Z-Score decreases which means bank stability decreases. In addition, it can be seen that the LIQ variable is statistically significant and correlates significantly with the ZScore, which is in line with the requirements of the Basel Accord on liquidity enhancement of banks.
TABLE 7

REGRESSION RESULTS REPLACE THE NPL WITH Z-SCORE

\begin{tabular}{lrr}
\hline \hline & Coeff. & Std. Err. \\
\hline LnCI & $-0.267 *$ & 0.108 \\
RGDP & 0.318 & 0.354 \\
LIQ & $0.247 * *$ & 0.101 \\
Efficiency & 0.204 & 0.576 \\
IRS & 0.768 & 0.621 \\
LnCAP & $0.571 * * *$ & 0.086 \\
Voac & $0.242 * *$ & 0.114 \\
Rol & -0.124 & 0.105 \\
Constant & $4.324 * * *$ & 0.282 \\
$\mathrm{R}^{2}$ & 0.15 & \\
$\mathrm{~N}$ & 393 & \\
$\mathrm{~F}$ value & $5.8 * * *$ & \\
\hline \hline
\end{tabular}

\section{CONCLUSION AND POLICY IMPLICATIONS}

Our paper explores whether corruption effects on the soundness of banking system in middleincome countries. We find important evidence that the relationship between corruption and ratio of non-performing loans was positive and hence deteriorates the soundness of the banking system. This result shows that as corruption increases, banks are more prone to taking risks, which boosts non-performing loan ratio and the crisis probability. The results of the robustness test of the model also give consistent results.

In addition, IRS, Efficiency, Liquidity, Liquidity Ratio (LnCAP) Freedom of speech (Voac) all affect the health of banking system in the middleincome countries.

From the results of this study, the article offers a number of policy implications for middle-income countries as follows:

\section{For the authorities}

The significantly positive relationship between corruption and non-performing loan ratio that represent the soundness of the banking system is a warning sign for policymakers. To cope with the financial implications of corruption requires a long-term combat, and public authorities need to enhance reforms, make refinement of cumbersome procedures especially in the field of licensing, construction, land, movable property...; to educate the public servants, minimizing the social custom of offering presents to officials (which often happens in Asian countries like China, Vietnam, India ...).

Freedom of speech (Voac) is strongly correlated with the level of bank soundness, which implies that, if the liberalization of information and press freedom are facilitated, the banking operations can be made safer and more stable. The result that Rol 
is positively related to the dependent variable is inconsistent with our expectation, but it implies the necessity of discipline in the long run.

For bank executives

In order to minimize the impact of corruption on bank soundness, attention should be paid to the training bankers both on skills and ethics. Strict adherence to the credit appraisal process, minimizing disbursement by orders, working honestly and transparently will help limit the misallocation of funds to poor projects.

The difference in interest rates (IRS) and the cost of management over total bank assets (Efficiency) are negatively related to banks' financial health. This result implies that to increase the asset quality and the soundness of the banking system, banks need to manage costs effectively, cut costs in the most reasonable ways without hurting banks' essential capabilities or reducing bank competitiveness. Effective cost management will narrow the gap between deposit rates and lending rates, and banks will reduce their willingness to take higher risks to maintain profitability.

Liquidity (LIQ) and capital adequacy ratio (LnCAP) are inversely correlated with nonperforming loan ratio. This result shows that banks need to ensure liquidity and have appropriate capital mobilizing schedule in place at the same time to ensure their stable and healthy operations. In addition, if banks are able to comply with the liquidity requirements and capital adequacy ratios under the Basel Convention, they should comply with this Treaty to improve the level of soundness of their operations.

\section{REFERENCES}

[1] P. Mauro, "Corruption and Growth," The Quarterly Journal of Economics, vol. 110, no. 3, pp. 681-712, 1995.

[2] A. I. Khwaja and A. Mian, "Do Lenders Favor Politically Connected Firms? Rent Provision in an Emerging Financial Market," The Quarterly Journal of Economics, vol. 120, no. 4, pp. 1371-1411, 2005.
[3] Charumilind, C., Kali, R., and Wiwattanakantang, Y., 'Connected Lending: Thailand before the Financial Crisis', Journal of Business, Vol. 79, 2006, pp. 181-218.

[4] Park J. (2012). Corruption, soundness of the banking sector, and economic growth: A cross-country study," Journal of International Money and Finance, vol. 31, no. 5, pp. 907-929, 2012.

[5] "Corruption Perceptions Index 2015," in Transparency International, Berlin, 2016.

[6] L. Laeven and F. Valencia, "Systemic banking crises database: An update," IMF Working Paper, WP/12/163, 2012.

[7] K. Bougatef, "The impact of corruption on the soundness of Islamic banks," vol. 15, no. 4, pp. 283-295, 2015.

[8] M. Chen, B. N. Jeon, R. Wang, and J. Wu, "Corruption and bank risk-taking: Evidence from emerging economies," Emerging Markets Review, vol. 24, pp. 122-148, 2015.

[9] J. Munshi, "Corruption in banking: a case study," Transparency International Working paper, Germany, 1999.

[10] B. Akins, Y. Dou, and J. Ng, "Corruption in bank lending: The role of timely loan loss recognition," Journal of Accounting and Economics, vol. 63, no. 2, pp. 454-478, 2017.

[11] "International Monetary Fund," Financial Soundness Indicators Compilation guide, 2006.

[12] H. L. Fofack, Non-performing loans in Sub-Saharan Africa: causal analysis and macroeconomic implications. World Bank Policy Research Working Paper, 2005.

[13] M. Nkusu, Nonperforming loans and macrofinancial vulnerabilities in advanced economies (no. 161). IMF Working Paper, 2011.

[14] W. Anjom and A. M. Karim, "Relationship between non-performing loans and macroeconomic factors with bank specific factors: a case study on loan portfoliosSAARC countries perspective," ELK ASIA Pacific Journal of Finance and Risk management, vol. 7, no. 2, pp. 2325-2349, 2016.

[15] L. Laeven and R. Levine, "Bank governance, regulation and risk taking," Journal of Financial Economics, vol. 93, no. 2, pp. 259-275, 2009.

[16] A. Demirgüç-Kunt and H. Huizinga, "Bank activity and funding strategies: The impact on risk and returns," Journal of Financial Economics, vol. 98, no. 3, pp. 626650, 2010.

[17] M. Köhler, "Which banks are more risky? The impact of business models on bank stability," Journal of Financial Stability, vol. 16, pp. 195-212, 2015. 


\title{
Tham nhũng và sự lành mạnh của hệ thống ngân hàng tại các quốc gia có thu nhập trung bình
}

\author{
Trần Hùng Sơn, Nguyễn Quỳnh Các Mai, Nguyễn Thanh Liêm
}

Tóm tắt-Bài viết này nghiên cứu tác động của tham nhũng đối với sự lành mạnh của hệ thống ngân hàng tại các quốc gia có thu nhập trung bình. Kết quả cho thấy tham nhũng làm giảm mức độ lành mạnh của hệ thống ngân hàng tại các quốc gia này. Điều này hàm ý tham nhũng tăng làm cho các ngân hàng dễ chấp nhận rủi ro hơn và làm tăng tỷ lệ nọ’ xấu, dẫn đến xác suất xảy ra khủng hoảng cao hơn. Kiểm thử biên mạnh (robustness test) cũng cho kết quả tương tự. Ngoài ra, kết quả cũng cho thấy các biến đặc điểm của ngân hàng và các biến liên quan đến quy định, chất lượng của các định chế cũng ảnh hưởng đến sức khỏe của hệ thống ngân hàng tại các quốc gia có thu nhập trung bình.

Tù khóa-Tham nhũng, hệ thống ngân hàng, sự lành mạnh, các quốc gia có thu nhập trung bình. 